\title{
PENINGKATAN HASIL BELAJAR KETERAMPILAN MENULIS PUISI DENGAN TEKNIK AKROSTIK MELALUI METODE GALLERY OF LEARNING (GALERI BELAJAR)SISWA KELAS VII SMPN 3 BONTONOMPO KABUPATEN GOWA.
}

\author{
Andi Paida \\ Fakultas Keguruan dan Ilmu Pendidikan, Universitas Muhammadiyah Makassar \\ paida@unismuh.ac.id
}

\begin{abstract}
ABSTRAK
Penelitian ini bertujuan untuk meningkatkan keterampilan menulis puisi dengan dengan teknik akrostik pada siswa kelasVII SMPN 3 Bontonompo Kabupaten Gowa. Penelitian ini bersifat deskriptif kulitatif.Jenis penelitian ini adalah penelitian tindakan kelas (Class Action Reaserch) yang terdiri dari dua siklus dimana dua siklus dilaksanakan sebanyak dua kali pertemuan. Prosedur penelitian meliputi perencanaan, pelaksanaan tindakan, observasi dan refleksi. Setting penelitiandilaksankan diSMPN 3 Bontonompo Kabupaten Gowa, subjek dalam penelitian ini adalah siswa kelasVII SMPN 3 Bontonompo Kabupaten Gowasebanyak 30 siswa. Hasil penelitian ini menunjukkan bahwa pada siklus pertama yang tuntas secara individual dari 33 siswa hanya 2 siswa dengan persentase 6,06\% yang memenuhi ketuntasan kriteria minimal (KKM) atau berada pada kategori rendah. Secara klasikal belum terpenuhi karena nilai rata-rata diperoleh sebesar 59,18\%\%. Sedangkan pada siklus II dimana dari 33 siswa dengan persentase $100 \%$ dan telah memenuhi KKM dan secara klasikal sudah terpenuhi yaitu nilai rata-rata yang diperoleh sebesar 77,54\% atau berada pada kategori tinggi.Berdasarkan hasil penelitian tersebut diatas, dapat disimpulkan keterampilan menulis puisi dengan teknik akrostik pada siswa kelas VII SMPN 3 Bontonompo Kabupaten Gowamelalui metode gallery of learning mengalami peningkatan.
\end{abstract}

\section{Kata Kunci : Hasil Belajar, Keterampilan Menulis Puisi dan Metode Gallery Of Learning}

\begin{abstract}
This study was aimed to improve the students' writing poem skill with acrostic technique at students' class VII SMPN 3 Bontonompo Gowa. The research was Class Action Research consisting of two cycles where two cycles of meetings held twice. Research procedure were includes planning, action, observation and reflection. The Setting was done at SMPN 3 Bontonompo Gowa, the subjects in this study were students of SMPN 3 Bontonompo class VII Gowa which consisted of 30 students. The results showed that in the first cycle were completed individually from 33 students' only two students with a percentage of $6.06 \%$ which meets the minimal completeness criteria (KKM) or are in the low category. Classically had not been met because the average value obtained was $59.18 \% \%$. While on the second cycle were 33 students with a percentage of $100 \%$ and has met KKM and classically been met and that the average value obtained for $77.54 \%$, or higher category. Based the research results mentioned above, it could be concluded the students' skills to write poetry with acrostic techniques in class VII SMPN 3 Bontonompo District Gowa gallery of learning method of learning has increased.
\end{abstract}

Key Words: writing poem skill, gallery of learning method

\section{PENDAHULUAN}

Bahasa Indonesia merupakan mata pelajaran yang bertujuan meningkatkan keterampilan siswa dalam berbahasa secara tepat dan kreatif, meningkatkan kemampuan berpikir logis dan bernalar, serta meningkatkan kepekaan perasaan dan kemampuan siswa untuk memahami dan menikmati karyasastra khususnya dalam menulis puisi. Karena pelajaran Bahasa Indonesia sangat penting maka perlu suatu cara untuk mengelola proses belajar mengajar sehingga pelajaran bahasa Indonesia mudah dicerna oleh siswa dengan baik dan lebih berarti serta bermanfaat bagi kehidupan mereka. Oleh karena itu, seorang guru harus pandaipandai memilih teknik pembelajaran dalam proses pembelajaran.

Berdasarkan hasil observasi peneliti di kelas VII SMPN 3 Bontonompo Kabupaten Gowadalam proses pembelajaran di kelas, kendala yang terkadang ditemui oleh siswa dalam menulis puisi antara lain, siswa kesulitan menemukan ide, kesulitan menentukan kata-kata pertama dalam menulis 
puisi, kesulitan mengembangkan ide menjadi puisi karena minimnya penguasaan kosakata, dan kesulitan menulis puisi karena tidak terbiasa mengemukakan perasaan, pemikiran, imajinasinya ke dalam puisi, kurangnya perhatian siswa dalam mengikuti proses pembelajaran. Akibatnya banyak siswa yang mampu menulis puisi tetapi tidak mampu menulis puisi jika difokuskan dengan menggunakan teknik tertentu.

Galeri belajar (Gallery of learning) siswa lebih mudah menentukan dan memahami konsep-konsep yang sulit jika mereka saling mendiskusikan masalah dan mendiskusikan dengan teman-temannya. Hal ini dapat membantu para siswa dalam meningkatkan pembelajaran bahasa Indonesia. Hasil pembelajaran bahasa Indonesia dengan gallery of learning diharapkan dapat memberikan pengalaman bermakna sehingga sukar dilupakan oleh siswa. Dengan penerapan gallery of learning siswa diharapkan mampu menghubungkan hal yang mereka pelajari dengan situasi dunia nyata sehingga menjadi pembelajaran yang mandiri.

Berdasarkan latar belakang yang telah diuraikan di atas, maka masalah yang diselidiki dalam penelitian ini dapat dirumuskan yaitu: "Bagaimanakah peningkatan hasil keterampilan menulis puisi dengan teknik akrostik pada mata pelajaran bahasa Indonesia melalui metode Gallery of Learning (Galeri Belajar) pada siswa kelas VII SMPN 3 Bontonompo Kabupaten Gowa. Penelitian ini bertujuan untuk meningkatkan hasil belajar keterampilan menulis puisi dengan teknik akrostik terhadap pelajaran bahasa Indonesia melalui Gallery of Learning (Galeri Belajar) pada siswa kelas VII SMPN 3 Bontonompo Kabupaten Gowa.

\section{METODE PENELITIAN}

Penelitian ini adalah penelitian tindakan kelas (PTK) yang merupakan sebagai peneliti yang berorientasi pada penerapan tindakan dengan tujuan peningkatan mutu atau pemecahan masalah pada kelompok subjek yang diteliti dan mengamati tingkat keberhasilan atau akibat tindakannya.

Lokasipenelitianiniadalahsiswa kelas VII SMPN 3 Bontonompo Kabupaten Gowa, dengan jumlah siswa terdiri dari 16 laki-laki dan 17 perempuan.Sampel dalam penelitian ini adalah sampel total yaitu semua populasi menjadi sampel.

\section{HASIL PENELITIAN DAN PEMBAHASAN}

\section{a. Hasil \\ Penelitian}

Penelitianinidilaksanakandaladuasiklusp adatahappelaksanaandenganmener

apkanmetodeGallery of Learning (Galeri Belajar) untuk meningkatkan hasil kemampuan menulis puisi kelas VII SMPN 3 Bontonompo Kabupaten Gowa dengan menggunakan teknik Akrostik.

\section{Siklus IAnalisis DataKuantitatif} Observasi

a) Pada awal pembelajaran siswa terlihat sangat senang dan antusias mendengarkan guru menjelaskan tujuan pembelajaran dan manfaat pembelajaran puisi dengan teknik akrostik. Begitu juga ketika peneliti mengkaitkan pembelajaran dengan tanya jawab secara perorangan, kompetensi sikap siswa pada umumnya mulai terbentuk, hanya ketika siswa belajar dalam kelompok dua hingga empat orang atau lebih, ada beberapa siswa yang belum mampu berinteraksi dengan teman kelompoknya dan sebagian siswa menggantungkan atau mengharapkan hasil kerja kawannya.

b) Sebagian siswa masih kurang berminat untuk mengikuti pelajaran. Hal ini di lihat dari kegiatan siswa dari dalam ruangan, masih ada siswa yang melakukan kegiatan lain pada proses belajar mengajar berlangsung seperti sering keluar masuk ruangan tanpa seizin dari peneliti, mengganggu temannya yang sedang memperhatikan guru mengajar, berbicara dengan teman yang ada disampingnya dan membuat suasana kelas menjadi ribut.

c) Pada penilaian individu beberapa siswa cenderung melihat buku cetak dan catatan yang ada di buku tulis.

Statistik hasil belajar siswa kelas VII SMPN 3 Bontonompo Kabupaten Gowadapat dilihat pada tabel 4.1

\section{Tabel 4.1Statistik Skor Hasil Belajar Siswa pada Siklus I}

\begin{tabular}{ll}
\hline Statistik & $\begin{array}{l}\text { Nilai } \\
\text { statistik }\end{array}$ \\
\hline Subyek & 33 \\
\hline Skor ideal & 100 \\
\hline
\end{tabular}




\begin{tabular}{ll}
\hline $\begin{array}{l}\text { Skor } \\
\text { tertinggi }\end{array}$ & 70 \\
\hline Skor rendah & 53 \\
\hline $\begin{array}{l}\text { Rentang } \\
\text { skor }\end{array}$ & 17 \\
\hline $\begin{array}{l}\text { Skor rata- } \\
\text { rata }\end{array}$ & $59,18 \%$ \\
\hline
\end{tabular}

Tabel 4.1 menunjukkan bahwa skor ratarata adalah $59,18 \%$ dari hasil belajar ideal 100 , skor tertinggi 70 , dan skor terendah adalah 53 dengan standar rentang skor 17 yang berarti hasil belajar yang terampil menulis puisi yang dicapai siswa kelas VII SMPN 3 Bontonompo Kabupaten Gowatersebar dari skor terendah 53 sampai skor ideal 100.

Apabila skor kemampuan awal siswa dikelompokkan kedalam lima kategori, maka diperoleh distribusi frekuensi skor yang ditunjukkan pada tabel 4.2 berikut:

Tabel 4.2 Distribusi Frekuensi dan Persentase Hasil Kemampuan Awal Siswa Kelas VII SMPN 3 Bontonompo Kabupaten Gowa

\begin{tabular}{llll}
\hline $\begin{array}{l}\text { Interval } \\
\text { Skor }\end{array}$ & Kategori & Frekuensi & $\begin{array}{l}\text { Persentase } \\
(\%)\end{array}$ \\
\hline $0-55$ & $\begin{array}{l}\text { Sangat } \\
\text { rendah }\end{array}$ & 9 & $27,3 \%$ \\
\hline $56-65$ & Rendah & 22 & $66,7 \%$ \\
\hline $66-75$ & Sedang & 2 & $6,0 \%$ \\
\hline $76-85$ & Tinggi & 0 & 0 \\
\hline $86-100$ & $\begin{array}{l}\text { Sangat } \\
\text { tinggi }\end{array}$ & 0 & 0 \\
\hline Jumlah & & 33 & $100 \%$ \\
\hline
\end{tabular}

Berdasarkan tabel 4.2 di atas dapat dikemukakan bahwa dari 33 siswa kelas kelas VII SMPN 3 Bontonompo Kabupaten Gowa terdapat 9 siswa atau sekitar 27,3\% siswa yang tingkat hasil belajar bahasa Indonesia dalam hal terampil menulis puisi pada kategori sangat rendah, pada kategori rendah ada 22 siswa atau sekitar $66,7 \%$, pada kategori sedang ada 2 siswa atau sekitar $6,0 \%$, kemudian tidak terdapat siswa yang hasil belajar bahasa Indonesia dalam hal terampil menulis puisi pada kategori tinggi, pada kategori sangat tinggi juga tidak ada.

\section{Refleksi}

1) Umumnya siswa menunjukkan antusias belajar yang positif, seperti menanggapi pertanyaan, keberanian mengajukan pertanyaan atau tanggapan pada guru, dan keinginan untuk menyelesaikan LKS. Namun karena siswa belum terbiasa dengan tindakan yang diberikan maka kelas menjadi agak gaduh sehingga pengelolaan kelas lebih ditekankan pada siklus II.

2) Masih ada beberapa siswa yang sulit dalam menyelesaikan LKS berkomunikasi dengan teman kelompoknya. Untuk itu guru harus membimbing siswa tersebut.

3) Dari hasil tes siklus 1, masih terdapat beberapa siswa yang mendapatkan nilai dibawah KKM. Hal ini disebabkan karena dalam kegiatan pembelajaran selama 3 pertemuan sebelumnya, beberapa siswa tersebut kurang aktif dalam pembelajaran, tidak memperhatikan penjelasan, dan tidak hadir dalam beberapa pertemuan.

Hasil belajar siswa pada Siklus I belum mencapai indikator keberhasilan yang telah ditetapkan yaitu tuntas individu jika memperoleh skor 75 dan tuntas klasikal apabila mencapai lebih atau sama dengan $85 \%$ dari jumlah siswa yang tuntas belajar, sehingga pelaksanaan tindakan masih dilanjutkan pada Siklus II dengan berbagai perbaikan berdasarkan pada refleksi pada Siklus I.

\section{Siklus IIAnalisis Data Kuantitatif}

Berdasarkan hasil deskriptif sebagaimana tercantum pada lampiran, maka rangkuman statistik hasil belajar siswa kelas VII SMPN 3 Bontonompo Kabupaten Gowadapat dilihat pada tabel 4.3

\section{Tabel 4.3 Statistik Skor Hasil Belajar Siswa pada Siklus II}

\begin{tabular}{ll}
\hline Statistik & $\begin{array}{l}\text { Nilai } \\
\text { statistik }\end{array}$ \\
\hline Subyek & 33 \\
\hline & \\
\hline Skor ideal & 100 \\
\hline $\begin{array}{l}\text { Skor } \\
\text { tertinggi }\end{array}$ & 80 \\
\hline Skor rendah & 75 \\
\hline $\begin{array}{l}\text { Rentang } \\
\text { skor }\end{array}$ & 5 \\
\hline Skor rata-rata & $77,54 \%$ \\
\hline
\end{tabular}

Tabel 4.3 menunjukkan bahwa skor ratarata adalah $77,54 \%$ dari hasil belajar ideal 100 , skor tertinggi 80 , dan skor terendah adalah 75 dengan standar rentang skor 5 yang berarti hasil belajar yang terampil menulis puisi yang dicapai siswa kelas VII SMPN 3 Bontonompo Kabupaten Gowatersebar dari skor terendah 75 sampai skor ideal 100. 
Pada siklus II ini, siswa sudah dapat mengerjakan soal-soal bahasa Indonesia dalam LKS secara individu. Selain itu terlihat keseriusan siswa dalam memperhatikan pelajaran dan mengerjakan soal-soal yang diberikan. Hasil belajar mereka dengan penerapan metode pembelajaran gallery of learning, pada siklus I skor rata-rata 59,18\% dan pada siklus II skor rata-rata meningkat 77,54\%. Secara umum dapat dikatakan bahwa seluruh kegiatan pada siklus II ini mengalami peningkatan dibanding pada siklus I. Hal ini terlihat pada kehadiran siswa meningkat, keseriusan siswa memperhatikan pelajaran, minat, sikap dan motivasi mereka juga meningkat.

Apabila skor kemampuan pada siklus II siswa dikelompokkan kedalam lima kategori, maka diperoleh distribusi frekuensi skor yang ditunjukkan pada tabel 4.4 berikut:

Tabel 4.4 Distribusi Frekuensi dan Persentase Skor Hasil Menulis Puisi pada Siklus II

\begin{tabular}{llll}
\hline $\begin{array}{l}\text { Interval } \\
\text { Skor }\end{array}$ & Kategori & $\begin{array}{l}\text { Frekuens } \\
\mathbf{i}\end{array}$ & $\begin{array}{l}\text { Persentase } \\
(\boldsymbol{\%})\end{array}$ \\
\hline $0-55$ & $\begin{array}{l}\text { Sangat } \\
\text { rendah }\end{array}$ & 0 & 0 \\
\hline $56-65$ & Rendah & 0 & 0 \\
\hline $66-75$ & Sedang & 16 & 48,48 \\
\hline $76-85$ & Tinggi & 17 & 51,52 \\
\hline $86-100$ & $\begin{array}{l}\text { Sangat } \\
\text { tinggi }\end{array}$ & 0 & 0 \\
\hline Jumlah & & $\mathbf{3 3}$ & $\mathbf{1 0 0}$ \\
\hline
\end{tabular}

Berdasarkan tabel 4.4 diperoleh data pemberian tugas siswa kela VII SMPN 3 Bontonompo Kabupaten Gowasetelah penggunaan metode gallery of learning dalam peningkatan kemampuan menulis puisi dengan teknik akrostik berhasil.Terdapattidak ada siswa pada kategori sangat rendah dan kategori rendah, pada kategori sedang terdapat 16 orang atau sekitar 48,48\%, kategori tinggi terdapat 17 siswa atau sekitar 51,52\%, sedangkan pada kategori sangat tinggi juga tidak terdapat siswa.

\section{b. Pembahasan}

Data yang diperoleh dari hasil tes hasil belajar dianalisis dengan statistik deskriptif. Sedangkan hasil observasi dianalisis secara kualitatif. Adapun untuk menentukan kategori adalah dengan menggunakan teknik kategorisasi standar berdasarkan ketetapan kementrian pendidikan nasional.

\section{RefleksiPelaksanaanTindakan I}

Pelaksanaan refleksi dilakukan peneliti bersama partner guru dengan melihat perbandingan antara data sebelum dilakukan tindakan dan setelah dilakukan tindakan pada siklus I. Peningkatan kemampuan siswa pada pembelajaran menulis puisi permulaan siklus I dapat diketahui dengan cara membandingkan perolehan persentase kemampuan siswa sebelum diberikan tindakan dan setelah diberikan tindakan.

Berdasarkan dari hasil penelitian dan saran partner, beberapa hal yang perlu diperhatikan pada tindakan selanjutnya adalah sebagai berikut:

(1) Metode yang digunakan ditambah metode kelompok agar semua siswa lebih aktif dan guru lebih maksimal dalam membimbing siswa,

(2) Mengatur waktu seefisien mungkin agar pembelajaran maksimal dan siswa masih memiliki waktu untuk bermain.

\section{RefleksiPelaksanaanTindakan II}

Upaya yang dilakukan untuk meningkatkan hasil belajar keterampilan menulis puisi dengan teknik akrostik melalui metode gallery of learning (galeri belajar) siswa kelas VII SMPN 3 Bontonompo Kabupaten Gowaguru selaku peneliti tidak terlepas dari perhatian dan perubahan sikap siswa dalam proses pembelajaran. Hal ini dapat dilihat pada lembar observasi yang dilakukan selama pelaksanaan tindakan.

Kegiatan siswa pada siklus II ini, semangat danperhatian siswa dalam proses pembelajaran meningkat. Hal ini tampak dari perhatian siswa dalam memperhatikan materi dan siswa yang mengajukan pertanyaan. Pada saat guru memantau siswa dalam mempelajari materi pada umumnya aktif. Selain itu, siswa yang melakukan kegiatan yang tidak relevan dengan pembelajaran mengalami penurunan.

Berdasarakan hasil observasi yang mempengaruhi semangat belajar meningkat, yaitu: (1) Guru memberikan penguatan dan memberikan motivasi pada siswa, (2) guru mengubah struktur dan variasi kelompok yaitu dengan memasukkan satu atau lebih tutor yang bisa membimbing teman kelompoknya agar setiap siswa mampu menulis puisi dengan baik, (3) guru menampilkan media yang menarik sesuai dengan konteks dan kebiasaan anak, (4) guru memberikan penilaian secara proporsional terhadap tugas yang dikerjakan oleh siswa. 
Analisis Tes Hasil Belajar

Adapun analisis deskriptif skor pemerolehan siswa setelah diterapkan metode pembelajaran gallery of learning dalam menulis puisi dengan teknik akrostik siswa kelas VII SMPN 3 Bontonompo Kabupaten Gowapada siklus I dan siklus II sebagai berikut:

Tabel 4.5Nilai pemerolehan Siklus I

\begin{tabular}{ll}
\hline Statistik & Nilai \\
\hline Subjek & 33 \\
\hline Skor Ideal & 100 \\
\hline Skor Tertinggi & 70 \\
\hline Skor Rendah & 53 \\
\hline Rentang Skor & 17 \\
\hline Skor Rata-rata & 59,18 \\
\hline Standar Deviasi & 5,13 \\
\hline
\end{tabular}

Tabel 4.6 Nilai Pemerolehan Siklus II

\begin{tabular}{ll}
\hline Statistik & Nilai \\
\hline Subjek & 33 \\
\hline Skor Ideal & 100 \\
\hline Skor Tertinggi & 80 \\
\hline Skor Rendah & 75 \\
\hline Rentang Skor & 10 \\
\hline Skor Rata-rata & 77,54 \\
\hline Standar Deviasi & 7,37 \\
\hline
\end{tabular}

Berdasarkan tabel 4.5 dan tabel 4.6 diatas bahwa nilai perolehan dari 30 siswa pada siklus I nilai tertinggi mencapai 70 dan meningkat pada siklus II mencapai 80, nilai rendah pada siklus I 53 dan meningkat pada siklus II mencapai 75, nilai rata-rata pada siklus I 59,18 dan meningkat 77,54 , nilai variansi pada siklus I 26,40 meningkat pada siklus II mencapai 54,35, standar deviasi pada siklus I 5,13 meningkat pada siklus II mencapai 7,37.

\section{Data Pemberian Tugas}

Meningkatnya data pemberian tugas dapat dilhat pada tabel distribusi frekuensi siklus I dan siklus II berikut:

Tabel 4.7 Perbandingan Distribusi Frekuensi dan Persentase Pemberian Tugas Siswa pada Siklus I dan Siklus II.

\begin{tabular}{|c|c|c|c|c|c|}
\hline \multirow[t]{2}{*}{ Skor } & \multirow[t]{2}{*}{ Kategori } & \multicolumn{2}{|c|}{ Frekuensi } & \multicolumn{2}{|c|}{ Persentase } \\
\hline & & $\begin{array}{l}\text { Siklus } \\
\text { I }\end{array}$ & $\begin{array}{l}\text { Siklus } \\
\text { II }\end{array}$ & $\begin{array}{l}\text { Siklus } \\
\text { I }\end{array}$ & $\begin{array}{l}\text { Siklus } \\
\text { II }\end{array}$ \\
\hline$\overline{0-55}$ & $\begin{array}{l}\text { Sangat } \\
\text { rendah }\end{array}$ & 9 & 0 & $27,3 \%$ & 0 \\
\hline $56-65$ & Rendah & 23 & 0 & $66,7 \%$ & 0 \\
\hline $66-75$ & Sedang & 2 & 16 & $6,06 \%$ & $\begin{array}{l}48,48 \\
\%\end{array}$ \\
\hline $76-85$ & Tinggi & 0 & 17 & 0 & $\begin{array}{l}51,52 \\
\%\end{array}$ \\
\hline $\begin{array}{l}86- \\
100 \\
\end{array}$ & $\begin{array}{l}\text { Sangat } \\
\text { tinggi }\end{array}$ & 0 & 0 & 0 & 0 \\
\hline \multicolumn{2}{|c|}{ Jumlah } & 33 & 33 & 100 & 100 \\
\hline
\end{tabular}

Pada tabel 4.7 adanya peningkatan skor hasil menulis puisi setelah pelaksanaan tindakan yang dilaksanakan selama dua siklus. Pada siklus I terdapat 8 siswa atau sekitar $27,3 \%$ pada kategori sangat rendah, sedangkan di siklus ke II tidak terdapat siswa. Kategori rendah pada siklus I terdapat 20 siswa atau sekitar 66,7\%, sedangkan pada siklus II juga tidak terdapat siswa. Kategori sedang pada siklus I terdapat 2 siswa atau sekitar $6,06 \%$, sedangkan pada siklus ke II terdapat 16 orang atau sekitar $48,48 \%$. Kategori tinggi pada siklus I tidak terdapat siswa, sedangkan pada siklus ke II terdapat 17 siswa atau sekitar 51,51\%. Kategori sangat tinggi pada siklus I dan siklus II juga tidak terdapat siswa.

Tabel 4.8 Deskripsi Ketuntasan Belajar Siswa Kelas VII SMPN 3 Bontonompo Kabupaten Gowa

\begin{tabular}{|c|c|c|c|c|c|}
\hline \multirow[t]{2}{*}{ Skor } & \multirow[t]{2}{*}{ Kategori } & \multicolumn{2}{|c|}{ Frekuensi } & \multicolumn{2}{|c|}{$\begin{array}{l}\text { Peresentese } \\
(\%)\end{array}$} \\
\hline & & $\begin{array}{l}\text { Siklus } \\
\text { I }\end{array}$ & $\begin{array}{l}\text { Siklus } \\
\text { II }\end{array}$ & $\begin{array}{l}\text { Siklus } \\
\text { I }\end{array}$ & $\begin{array}{l}\text { Siklus } \\
\text { II }\end{array}$ \\
\hline$\overline{0-74}$ & $\begin{array}{l}\text { Tidak } \\
\text { tuntas }\end{array}$ & 31 & 0 & $94 \%$ & 0 \\
\hline $75-100$ & Tuntas & 2 & 33 & $6,06 \%$ & $100 \%$ \\
\hline
\end{tabular}

Berdasarkan tabel 4.8 di atas bahwa siswa yang berada pada kategori tidak tuntas pada siklus I sebanyak 31 siswa atau sekitar 94\%, sedangkan pada siklus II tidak terdapat siswa. Kategori tuntas pada siklus I terdapat 2 siswa atau sekitar $6,06 \%$, sedangkan pada siklus II terdapat 33 siswa atau sekitar $100 \%$ yang telah 
tuntas belajar. Ini berarti ketuntasan belajar sudah memuaskan secara keseluruhan.

\section{Simpulandan Saran}

\section{Kesimpulan}

Berdasarkan penilaian hasil pembelajaran diperoleh kesimpulan bahwa pembelajaran dengan menggunakan media gambar dapat meningkatkan hasil belajar. Pada siklus I tingkat ketuntasan siswa mencapai 94\% dengan kemampuan kurang memuaskan secara keseluruhan. Pada siklus II siswa mengalami peningkatan dari kegitan awal kurang menjadi sanagat baik dengan tingkat ketuntasan 100\%.Peningkatan hasil belajar Bahasa Indonesia dilihat dari rata-rata siklus I $(59,18 \%)$ dan pada siklus II meningkat menjadi $(77,54 \%)$ Terjadinya peningkatan persentase kehadiran siswa, perhatian minat, keaktifan siswa terutama mengerjakan soalsoal dipapan tulis, serta semangat belajar siswa dalam proses belajar mengajar.

\section{Saran}

a.Perlunya peningkatan kompetensi guru dalam menerjemahakan dan mengimplementasikan pembelajaran puisi, penyediaan sarana-prasarana, peningkatan motivasi dan kreatifitas siswa dan evaluasi yang meningkatkan kompetensi siswa dalam bersastra

b. Membuat karya inovatif untuk keperluan proses pembelajaran yang kreatif, produktif dan kondusif mutlak harus dilakukan oleh guru.

c.Perlu penelitian lebih lanjut untuk metode yang lain pada mata pelajaran yang sama, agar diperoleh keragaman bahan pertimbangan pendekatan mana yang terbaik untuk mengajarkan materi bahasa Indonesia.

\section{DAFTAR PUSTAKA}

Arikunto, suharsimi. 2002. Penelitian

Tindakan Kelas. Jakarta: Rineka Cipta

Dimyati. 2002. Belajar dan

Pembelajaran. Jakarta: Rineka Cipta

Hisyam Zaini, 2007. Strategi Pembelajaran Aktif, Yogyakarta: Center For Teaching Staff Develofment

Idawati. 2011. Penerapan Learning Community dalam Pembelajaran Keterampilan
Berbicara Bahasa Indonesia Kelas XI SMA Negeri 1 Bantimurung Kabupaten Maros. Skripsi. Makassar: Unismuh

Kahar. 2012. Peningkatan Hasil Pembelajaran Bahasa Indonesia melalui Penerapan Metode Fun Learning pada Siswa Kelas VII MTs DDI Mattoanging. Skripsi. Makassar: Unismuh

Silberman. 2006. Metode Pembelajaran Gallery of learning (online) (http://www.referensimakalah.com/201 3/01/metode-gallery-of-learningdalam-pembelajaran.html/, diakses 25 Mei 2013)

Slameto. 1991. Proses Belajar Mengajar dalam Sistem Kredit Semester. Jakarta: Depdikbud.

Sugiyono. 2011. Metode Penelitian Kombinasi. Bandung: Alfabeta

Sudirman. 2011. Peningkatan Hasil Belajar Bahasa Indonesia melalui Pendekatan Quantum Teaching MTS. Guppi Rannaloe Kecamatan Bungaya Kabupaten Gowa. Skripsi. Makassar: Unismuh. 